\title{
Invasion of Pontoscolex corethrurus (Glossoscolecidae, Oligochaeta) in landscapes of the Amazonian deforestation arc
}

\author{
Raphael Marichal ${ }^{\mathrm{a}, \mathrm{c}}$, Alex Feijoo Martinez ${ }^{\mathrm{b}}$, Catarina Praxedes ${ }^{\mathrm{c}}$, Dario Ruiz $^{\mathrm{b}}$, Andres F. Carvajal $^{\mathrm{b}}$, \\ Johan Oszwald $^{\mathrm{d}}$, Maria del Pilar Hurtado ${ }^{\mathrm{e}}$, George G. Brown ${ }^{\mathrm{f}}$, Michel Grimaldi ${ }^{\mathrm{a}}$, Thierry Desjardins ${ }^{\mathrm{a}}$, \\ Max Sarrazin $^{a}$, Thibaud Decaëns ${ }^{g}$, Elena Velasquez ${ }^{\mathrm{i}}$, Patrick Lavelle ${ }^{\mathrm{a}, \mathrm{e}, *}$ \\ a Université Pierre et Marie Curie and IRD, UMR BIOEMCO 211, Centre IRD Ile de France, 32 Av. Henri Varagnat, 93143 BONDY Cedex, France \\ b Universidad Tecnológica de Pereira, Apartado Aéreo 97 Pereira, Colombia

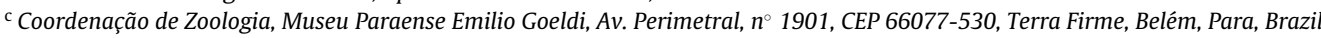 \\ d UMR CNRS LETG 6554, Laboratory of Geography and Remote Sensing COSTEL, Université de Rennes 2, France \\ e Centro Internacional de Agricultura Tropical (CIAT), TSBF_LAC, ap aereo 6713 Cali, Colombia \\ ${ }^{\mathrm{f}}$ Embrapa Florestas, Estrada da Ribeira, Km. 111, C.P. 319, Colombo-PR 83411-000, Brazil \\ ${ }^{g}$ ECODIV, Faculté des Sciences Er des Techniques, Bâtiment IRESE A, Place Emile Blondel, Université de Rouen, F-76821 Mont Saint Aignan Cedex, France \\ ${ }^{\mathrm{i}}$ Universidad Nacional de Colombia, Palmira, Colombia
}

\section{A R T I C L E I N F O}

\section{Article history:}

Received 19 June 2010

Received in revised form 1 September 2010 Accepted 6 September 2010

\section{Keywords:}

Invasive earthworms

Land transformation

Amazonia

\begin{abstract}
A B S T R A C T
Pontoscolex corethrurus (Glossoscolecidae, Oligochaeta) is an invasive endogeic earthworm that has colonized most land transformed by human activities in the humid tropics. When installed, populations can change soil physical properties, biogeochemical processes and microbial communities. The aim of this study was to determine whether $P$. corethrurus establishment is a result of (1) a competitive exclusion of native earthworm species or (2) the exploitation of a new niche created by anthropogenic disturbance that native earthworm species cannot use. We tested these hypotheses by doing a survey of earthworm communities in 270 sites that represented the diversity of land use systems encountered in two contrasted regions of the Amazonian arc of deforestation located in Brazil and Colombia respectively. When present in forests, $P$. corethrurus had no negative effect on the native species communities that had similar (epigeic species) or even higher densities (endogeic species) in the presence of the invasive species. These results suggest the absence of competitive exclusion.

The first two axes of a PCA multivariate analysis of communities represented the densities of native species (axis 1 ) and $P$. corethrurus (axis 2 ) respectively. This suggests that respective densities of the two groups respond to different conditions and that their variations are independent. The density of $P$. corethrurus co-varied with soil $\mathrm{N}$ content and $\mathrm{pH}$ in Colombian sites while the densities of other species did not. Our results thus suggest that this invasive species, unlike native species, is able to feed and develop in environments where litter resources are decreased while soils have been enriched in $C$ and nutrients by deforestation and burning. We discuss the reasons why some primary forests in Central America have large populations of $P$. corethrurus.
\end{abstract}

(C) 2010 Elsevier B.V. All rights reserved.

\section{Introduction}

Pontoscolex corethrurus (Glossoscolecidae, Oligochaeta) is an invasive endogeic earthworm that has colonized most disturbed soils in the tropics (Lavelle et al., 1987). When established populations can affect soil physical properties (Hallaire et al., 2000; Chauvel et al., 1999; Barros et al., 2001), modify biogeochemical processes (Gonzales and Zou, 1999; Liu and Zou, 2002), plant

\footnotetext{
* Corresponding author at: Centro Internacional de Agricultura Tropical (CIAT), TSBF LAC, ap aereo 6713 Cali, Colombia. Tel.: +572 44532 47; fax: +57 24450073.

E-mail address: Patrick.lavelle@ird.fr (P. Lavelle).
}

communities (Zou, 1993) and microbial communities (McLean et al., 2006). Although this species has been repeatedly reported to enhance nutrient release in soil (Lavelle et al., 1992; LopezHernandez et al., 1993; Chapuis-Lardy et al., 1998), plant growth and tolerance to phytoparasitic nematodes (Pashanasi et al., 1996; Brown et al., 1999; Lafont et al., 2007), the activity of these worms may sometimes promote soil compaction, especially when populations of other "decompacting" species are depressed by disturbance (Rose and Wood, 1980; Alegre et al., 1996; Hallaire et al., 2000). $P$. corethrurus has tolerance for a wide range of soil conditions, and its expansion seems to be only limited by temperature (reproduction occurs between 23 and $27^{\circ} \mathrm{C}$ ), and soil moisture values, with an optimal around $-0.01 \mathrm{MPa}$ water tension ( $\mathrm{pF} 2$ ) (Lavelle 
Table 1

Types of land use observed in Brazil and Colombia sampling areas.

\begin{tabular}{|c|c|c|c|}
\hline \multirow[t]{2}{*}{ Land use } & \multirow[t]{2}{*}{ Description } & \multicolumn{2}{|c|}{ Number of sites } \\
\hline & & Brazil & Colombia \\
\hline Forests & Conserved or exploited forests & 49 & 0 \\
\hline Fallows after crop & Secondary forests developed in abandoned cropland & 17 & 0 \\
\hline Fallows after pasture & Secondary forests developed in abandoned pastures & 13 & 19 \\
\hline Pastures & Pastures with Brachiaria spp., pastures invaded by Babaçu (Amazonian palm tree) or other trees & 38 & 92 \\
\hline Crops & Cassava, rice or maize crops & 14 & 0 \\
\hline Plantations & Cacao, rubber-tree, agro-forestry systems & 4 & 24 \\
\hline
\end{tabular}

et al., 1987). The density of $P$. corethrurus populations is often inversely correlated with the density of other earthworm species (Lapied and Lavelle, 2003). P. corethrurus is invading the Amazon region and its proliferation seems to be linked to deforestation and disturbance of the Amazonian landscape since this species mostly occurs in cropland (Lavelle et al., 1987; Nunes et al., 2006; Rossi et al., 2010) and pastures (Barros et al., 2003; Sanchez-de Leon et al., 2004; Nunes et al., 2006). However, P. corethrurus was found to be dominant in the primary forests of the Manzillo Wildlife Refuge and of the Tortuguero National Park in CostaRica (Hendrix et al., 2006; Lapied and Lavelle, 2003), in tropical rainforests of Puerto-Rico (Zou and Gonzalez, 1997) and in cloud forest at the top of Luquillo Mountains (Hendrix et al., 1999; Liu and Zou, 2002), indicating that this species also lives in little disturbed ecosystems. The occurrence of this invasive species in undisturbed ecosystems suggests that population may establish through a process of competitive displacement of native species. Studies based on overlap in ${ }^{13} \mathrm{C}$ and ${ }^{15} \mathrm{~N}$ signals suggest direct competition for food between native species and $P$. corethrurus (Hendrix et al., 1999), although microcosms experiments failed to show any niche overlap (Lachnicht et al., 2002) and that $P$. corethrurus had no effect on growth, survival or fertility of Balanteodrilus pearsei (Ortiz-Ceballos et al., 2005). Overall, these results suggest potential direct competition between $P$. corethrurus and native species.

In this study, we sampled primary forests and a wide range of derived systems, with different plant covers, contrasted ages since the first deforestation occurred and a great diversity of land use histories. We assumed that competitive exclusion is demonstrated if $P$. corethrurus is found with equal frequencies in disturbed or undisturbed sites and a negative correlation is observed between its population density and populations of native species (Hendrix et al., 2006). An alternative hypothesis is that $P$. corethrurus populations develop in new niches created by human disturbance, which native species cannot use. If this is true, $P$. corethrurus will be found mostly in disturbed sites and no difference should be found in density of other species in undisturbed sites with or without $P$. corethrurus. In this case, elimination or decrease in native species would be independent of the establishment of $P$. corethrurus. We tested these two hypotheses through a survey of earthworm communities in the diversity of land use systems encountered in the Amazonian arc of deforestation.

\section{Materials and methods}

\subsection{Study sites}

Sampling was conducted in two regions of Brazil and Colombia, outside the assumed origin center of $P$. corethrurus, which is located in the Guyanese plateau (Righi, 1984). In each country we chose three groups of 51 contiguous farms forming landscape windows with different histories and ages of colonization. Brazilian sites, located in the south of the State of Pará had been recently colonized by farmers (10-15 years ago). The three land- scape windows had very different historical and socio-economical conditions: Palmares II is an old "fazenda" which was invaded by the "Movimento dos Trabalhadores rurais sem Terra - MST" (Landless Workers' Movement). Farms of Pacajá are localized on a trail ("Travessão Sul 338") perpendicular to the Trans-Amazonian highway. The Maçaranduba locality is occupied by a group of agroextractivist farmers who increasingly rely on cattle ranching and annual crops. Deforestation started respectively in 1990, 1994 and 1997 in the three landscape windows. The three Colombian landscape windows, located in the Caqueta Department (South West of Colombia) are allocated to three dominant farming systems: conventional agriculture, agro-sylvo-pastoral and agro-forestry respectively. Deforestation started between 1940 and 1950 at all three landscape windows.

Each group of 51 contiguous farms of each landscape window was further divided into three sub-windows of 17 farms. Earthworm sampling was conducted in three farms representative of general socio-economic conditions in each sub-window (Arnauld de Sartre et al., 2010). In each of the 54 farms thus sampled, five sampling points (sites) were located $200 \mathrm{~m}$ apart along a diagonal transect, thus representing a total of 270 sites (135 in Brazil and 135 in Colombia).

\subsection{Sampling methodologies}

The TSBF method (Anderson and Ingram, 1993) was used between April and June 2008 to sample earthworms. In each of the 270 site, a central soil monolith $(25 \mathrm{~cm} \times 25 \mathrm{~cm}, 20 \mathrm{~cm}$ depth $)$ and two additional soil monoliths $(25 \mathrm{~cm} \times 25 \mathrm{~cm}, 10 \mathrm{~cm}$ depth) were dug out $5 \mathrm{~m}$ East and West respectively from the central monolith. We did not correct for earthworms missed in the $10-20 \mathrm{~cm}$ layer of the extra monoliths since only $9.7 \%$ of individuals were found below $10 \mathrm{~cm}$. One sampled unit is thus composed of 3 monoliths. Eight hundred and ten monoliths were thus taken and handsorted. Earthworms were conserved in $4 \%$ formaldehyde, sorted, measured and identified at the species or morphospecies level and finally separated into three ecological categories: anecic, endogeic and epigeic, according to Bouché (1977) and Lavelle (1981).

\subsection{Land use categories}

The landscape mosaic was analysed from satellite images and six types of land use were recognized after field verification (Table 1).

\subsection{Soil analysis}

Texture (percentage of sand, silt and clay), total soil C (at 10, 20 and $30 \mathrm{~cm}$ depth), total soil $\mathrm{N}$ (at 10,20 and $30 \mathrm{~cm}$ depth), P contents, Al, Ca, Mg, K, total bases, CEC (Cation Exchange Capacity), Ve (CEC/total bases), $\mathrm{NH}_{4}, \mathrm{pH}$ and bulk densities (2,5 and $10 \mathrm{~cm}$ depth), resistance to penetration and sheer strength resistance were measured using standard methodologies (Anderson and Ingram, 1993). Soil C and soil N stocks were measured down to $30 \mathrm{~cm}$ depth since a 


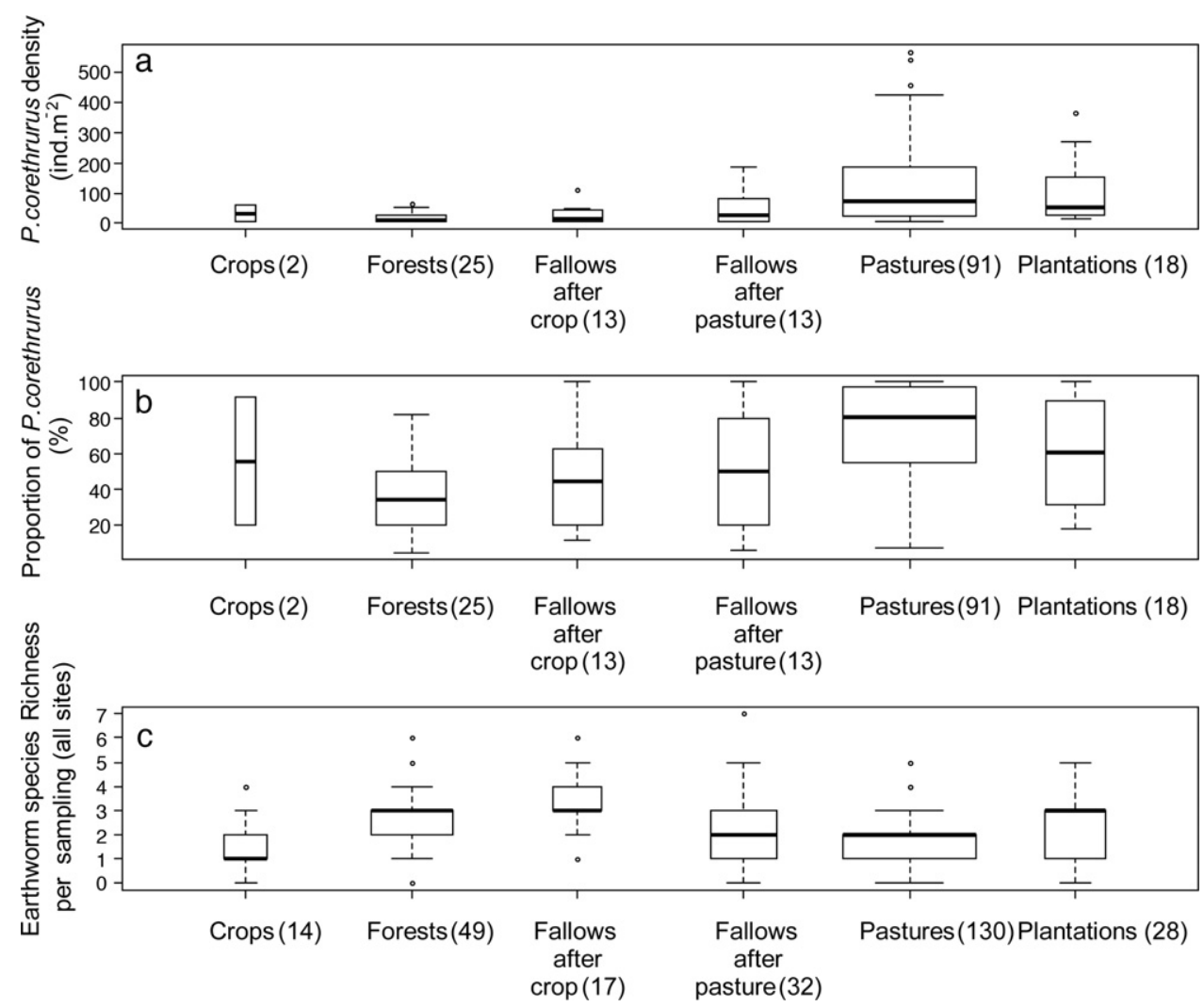

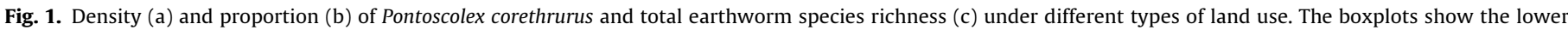

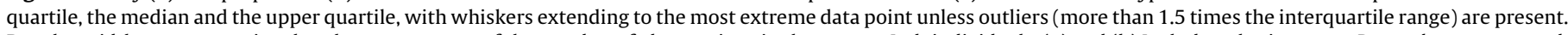

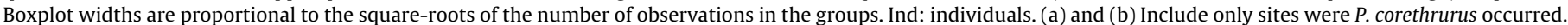
In brackets the numbers of sites.

few earthworms may get down to $30 \mathrm{~cm}$ depth and therefore alter this parameter.

\subsection{Statistical analysis}

Data were converted into densities per square meter (ind. $\mathrm{m}^{-2}$ ) for each site. We compared $P$. corethrurus density, percentage of $P$. corethrurus in the whole community and species richness across land uses. We also compared the respective occurrences of four situations across different types of land use: (0) no earthworms, (1) P. corethrurus only, (2) coexistence of $P$. corethrurus and other species and (3) other species but not $P$. corethrurus. We used the Wilcoxon rank sum test to compare the effect of the presence of $P$. corethrurus on other species communities in undisturbed ecosystems (forests). A Principal Component Analysis (PCA) of earthworm communities assessed through their distribution among ecological categories was carried out in each country on sites where P. corethrurus had been found. We assigned other earthworms to ecological categories rather than species because most species were rare and a great number of zero values in tables would invalidate PCA analysis. Four variables were then used: $P$. corethrurus, native endogeic, native epigeic and native anecic species densities. The matrix of Brazilian sites contained 68 rows (sampled sites in which $P$. corethrurus was present) and 4 columns ( $P$. corethrurus, native endogeics, native epigeic and native anecic earthworm densities) (PCA 1); the table of Colombian data had 94 rows and 3 columns ( $P$. corethrurus, native epigeic and native endogeic earthworm densities) (PCA 2). All statistical analyses were performed with $R$ software (Ihaka and Gentleman, 1996; R-Development-Core-Team, 2009) and the package ade4 for multivariate analysis (Chessel et al., 2004; Dray and Dufour, 2007; Dray et al., 2007).

\section{Results}

\subsection{Earthworm communities and the occurrence of $P$. corethrurus}

Total earthworm density ranged from 0 to 567 ind. $\mathrm{m}^{-2}$ with an average 93.5 ind. $\mathrm{m}^{-2}$. Earthworms were totally absent from 23 sites in Colombian landscape windows, mostly degraded pastures and plantations, and from 8 sites in Brazilian landscape windows. $P$. corethrurus density varied from 0 to 567 ind. $\mathrm{m}^{-2}$, with an average 54.1 ind. $\mathrm{m}^{-2}$. They occurred in 68 sites ( $50.4 \%$ of sampled sites) in Brazilian landscape windows and 94 sites (69.6\% of sampled sites) in Colombian landscape windows.

Where $P$. corethrurus occurred, the average density of this species was 90.2 ind. $\mathrm{m}^{-2}$, ranging from 5.3 to $567 \mathrm{ind} . \mathrm{m}^{-2}$. Average densities of $P$. corethrurus where this species occurred varied significantly among land-uses (Kruskal-Wallis rank sum test, $p<0.01$ ), from 67.6 ind. $\mathrm{m}^{-2}$ in forests to 100.1 ind. $\mathrm{m}^{-2}$ in pastures, with intermediate values in plantations and fallows (Fig. 1a). On average $P$. corethrurus represented $61.5 \pm 2.5$ (S. E.) \% of overall earthworm density in all sites where they occurred. This proportion varied from $35.1 \pm 3.9 \%$ in forests to $79.8 \pm 2.9 \%$ in pastures (Fig. 1 b). P. corethrurus was thus found in $70.0 \%$ of pastures $(73.9 \%$ in Colombia and $60.5 \%$ in Brazil, respectively) and coexisted with other species in $53.8 \%$ of pasture (Table 2 ). In forests, P. corethrurus occurred in $51.0 \%$ of sampled sites and was never found alone. While a majority of sites dedicated to crops (85.7\%) and the two types of fallows ( $53.1 \%$ and $47.1 \%$ respectively) had no P. corethrurus, this species coexisted with other species in a majority $(57.1 \%)$ of sites in plantations.

Average species richness was 2.1 species and varied from $2.0 \pm 0.4$ (crops) to $2.3 \pm 0.3$ (fallows after crops, Fig. 1c) with signif- 
Table 2

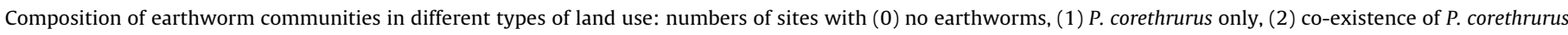
with native species, (3) other species, but no $P$. corethrurus.

\begin{tabular}{|c|c|c|c|c|c|}
\hline Land use & No earthworms & P. corethrurus only & Coexistence & Other species only & Total \\
\hline Forests & 4 & 0 & 25 & 20 & 49 \\
\hline Fallows after crops & 0 & 2 & 11 & 4 & 17 \\
\hline Fallows after pasture & 3 & 3 & 11 & 15 & 32 \\
\hline Plantations & 4 & 2 & 16 & 6 & 28 \\
\hline Crops & 3 & 0 & 2 & 9 & 14 \\
\hline Pastures & 24 & 21 & 70 & 15 & 130 \\
\hline Total & 38 & 28 & 121 & 69 & 270 \\
\hline
\end{tabular}

icant differences among land uses (Kruskal-Wallis rank sum test, $p<0.01)$.

\subsection{Native species densities in invaded and non-invaded sites in forests}

In Brazilian forests sampled, the densities of epigeic species were not affected by the presence of $P$. corethrurus (Wilcoxon rank sum test, $p>0.05$ ). The densities of native endogeic species was even higher (Wilcoxon rank sum test, $p<0.01$ ) in forest sites where $P$. corethrurus occurred than in the other sites. No forest was sampled in Colombia.

\subsection{Co-variation of earthworm communities with soil and land use characteristics}

The first two axes of the PCA performed on Colombian communities with $P$. corethrurus, accounted for $72.7 \%$ of the explained inertia (39.0\% and 33.7\% respectively, Fig. 2). Axis 1 markedly separated epigeic species (associated with fallow systems) from $P$. corethrurus (mainly associated with pastures) respectively. Axis 2 ranked sites according to native endogeic species density. Differences in communities from different types of land use were significant ( $9 \%$ variance explained, $p$-value $<0.01$, Monte Carlo test).
Significant co variation (co inertia analysis: $\mathrm{RV}=0.09, p$ value $<0.02$, Monte Carlo test) was observed among earthworm communities and soil data sets in Colombian sites where $P$. corethrurus occurred. The first axis of the co-inertia (57.4\% variance explained, Fig. 3) separated (1) pH, N contents from (2) $\mathrm{Al}, \mathrm{NH}_{4}$, CTC. The second axis of the co-inertia (24.2\% variance explained) separated (1) silt from (2) clay content. P. corethrurus density covaried with silt, $\mathrm{pH}$ and $\mathrm{N}$ soil contents (down to $30 \mathrm{~cm}$ depth) and was separated from native species densities along axis 1 , and native endogeic densities along axis 2.

The first two axes of the PCA performed on Brazil earthworm communities that comprised $P$. corethrurus accounted for $63.1 \%$ of the total explained inertia ( $35.4 \%$ and $27.7 \%$ respectively, Fig. 4 ). Axis 1 ranked the sites according to the densities of epigeic and native endogeic species. Axis 2 classified the sites according to $P$. corethrurus and anecic species densities. The effect of land use on communities was not significant.

Co inertia analysis among earthworm communities and soil data sets in Brazilian sites where $P$. corethrurus occurred was not statistically significant $(p$-value $=0.06$, Monte Carlo test).

\section{Discussion}

The species diversity of earthworm communities was lower in pastures, fallows after pasture, annual crops and plantations than

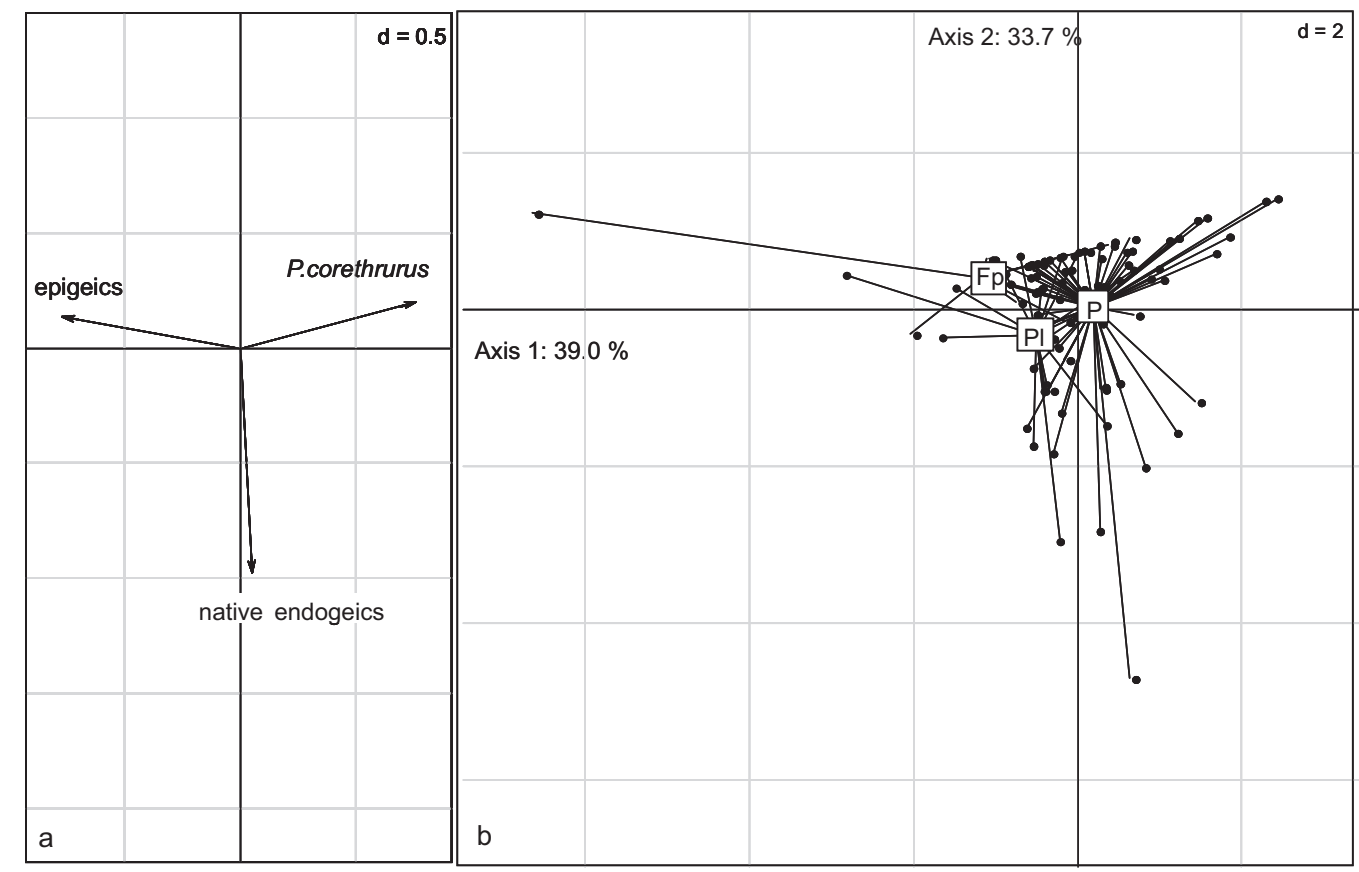

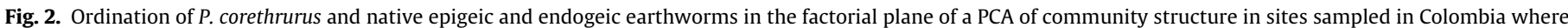

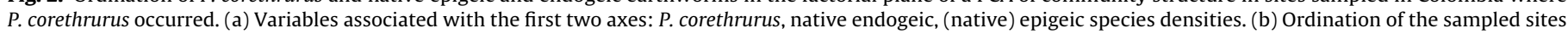

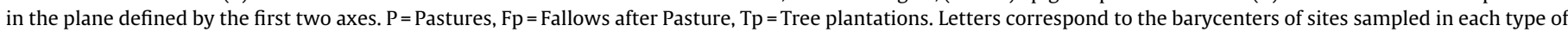
land use. (Monte Carlo test on land uses significant, $p<0.02$ ). 


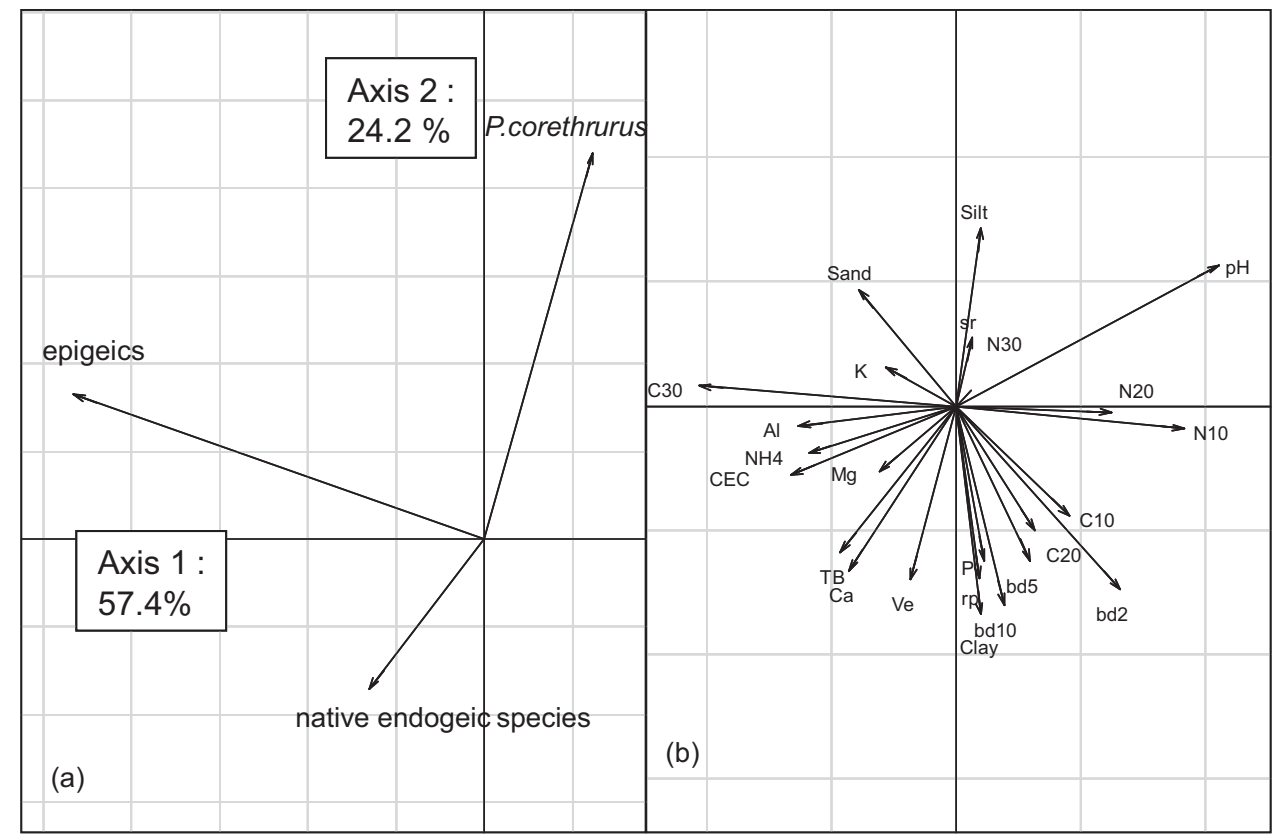

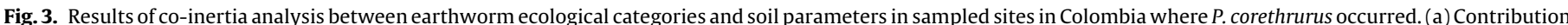

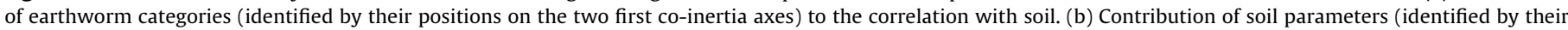

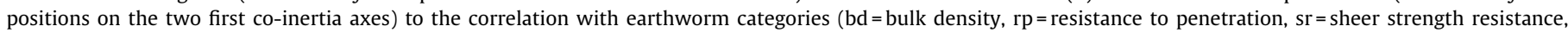
$\mathrm{TB}=$ Total Bases). $\mathrm{C}, \mathrm{N}$ and bd numbers correspond to soil stratum. $\mathrm{RV}=0.08, p$-value $=0.018$.

in forests and fallows after annual crops. P. corethrurus was found principally in pastures and fallows and rarely in natural forests. Across the sites where they had become established, $P$. corethrurus populations were actually dominant (mean proportion $>50 \%$ ) in every type of land use except in forests. These results confirm previous observations suggesting a strong association of this species with man-made ecosystems (Lavelle and Pashanasi, 1989; Barros et al., 2003; Brown et al., 2006; Rossi et al., 2010). Coexistence with native species was frequently observed in pastures and tree plantations, the most disturbed land-uses. Cases of monospecific communities of $P$. corethrurus were relatively rare, except in pas- tures (16.2\% of sampled sites). These results suggest that land use may determine the occurrence of $P$. corethrurus and its coexistence with other species. As a matter of fact, land use was significantly related to earthworm community structure in Colombian sites, but less so in the Brazilian sites. Establishment of $P$. corethrurus population was probably much more recent in Brazil where deforestation had started only 10-15 years ago than in Colombia, where it occurred 40-60 years ago. We also know from unpublished analyses of land use changes over time (Johan Oszwald, Valery Gond et al., unpub. data) that in periods following deforestation, land cover is highly dynamic whereas in areas deforested for longer periods,

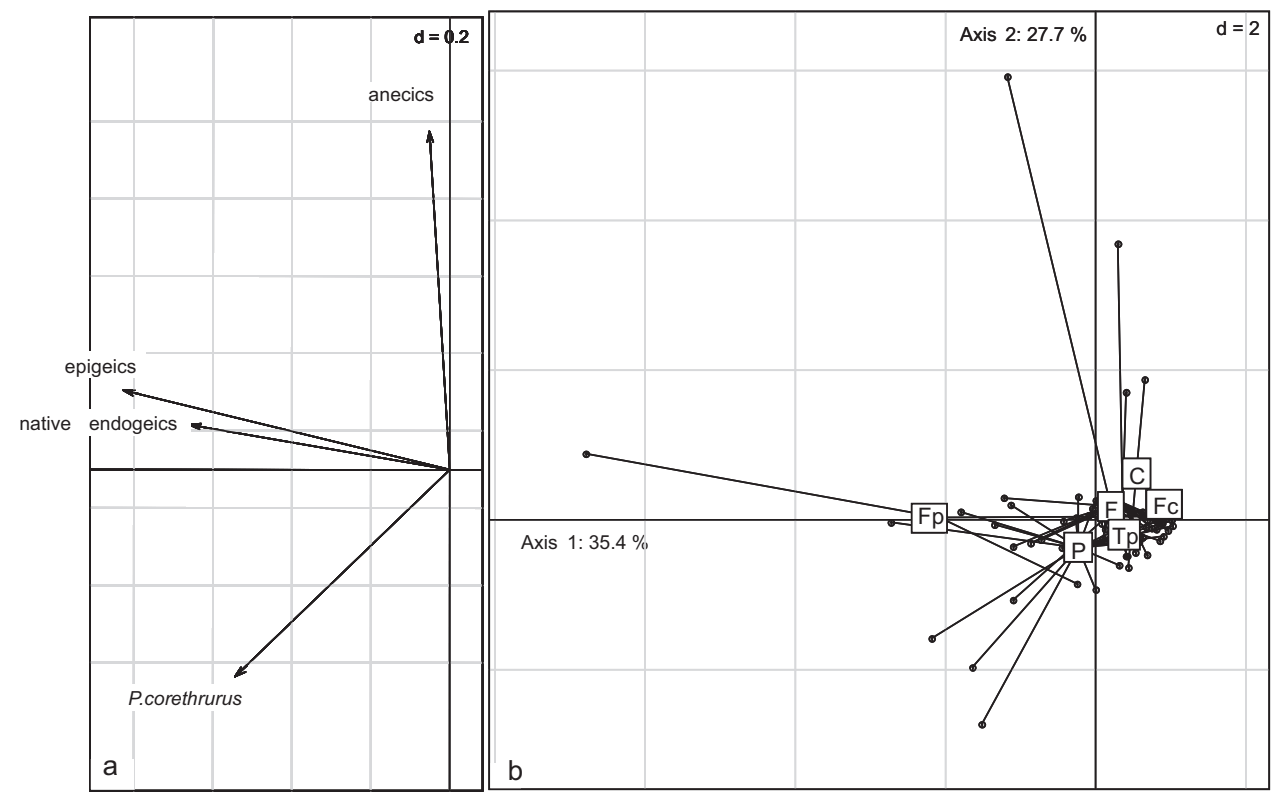

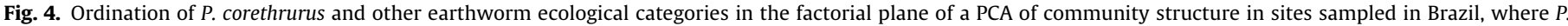

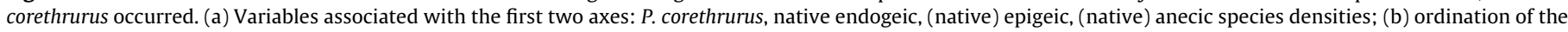

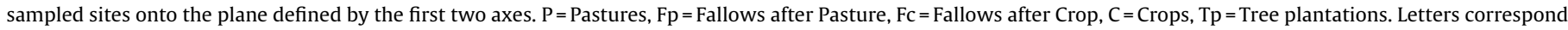
to the barycenters of sites sampled in each type of land-use. (Monte Carlo test on land-uses non-significant). 
we can expect to have more stable land use patterns that may exert their influence over communities.

When present in forests, the invasive $P$. corethrurus had no negative effect on native species communities that had similar (epigeic species) or even higher densities (endogeic species). This important observation invalidates the hypothesis of competitive exclusion of other species by $P$. corethrurus, at least in the conditions observed at our sites.

Another argument against competitive exclusion is provided by results of the PCA analyses of earthworm communities. On the PCA of Colombian sites, $P$. corethrurus density was projected opposite to epigeic species density on axis 1 whereas axis 2 was clearly determined by native endogeic species. According to the logics of the PCA analyses, factors that determine the abundance of the two groups are therefore independent. We can conclude that in Colombian landscapes, $P$. corethrurus density is sensitive to other parameters than native endogeic species densities. Rather similar results have been obtained for Brazil, although less clear.

Our results therefore suggest that the replacement of native species by $P$. corethrurus is a result of changes in the environment that differently affect both groups of species rather than an effect of the competition between an invasive species and less competitive native species. While native species tend to disappear as a result of the disturbance that destroys their habitats and reduces their food sources, $P$. corethrurus occupies a new niche created by this perturbation, that is soils with increased $\mathrm{pH}, \mathrm{C}$ and nutrient contents. They then adjust their population density to organic matter and $\mathrm{N}$ availability in soil. In the factorial plane defined by co inertia analysis among soil and earthworm community analyses, $P$. corethrurus density projected close to $\mathrm{pH}$ and $\mathrm{N}$ content indicating higher carrying capacities for this species for soils with relatively high $\mathrm{N}$ contents and $\mathrm{pH}$. A significant correlation was actually observed between $P$. corethrurus densities and values of $\mathrm{N}$ contents in the different soil strata down to $30 \mathrm{~cm}(p<0.01)$ in all sites in Brazil and Colombia where the species was present. The relationship with $\mathrm{pH}$ was almost significant considering all sites $(p=0.051)$, and significant in Colombian sites only $(p<0.05)$. These results are consistent with experimental or field studies that show an influence of soil $\mathrm{pH}$ on $P$. corethrurus densities (Garcia and Fragoso, 2002). Increases in $\mathrm{pH}$ are a well known consequence of the conversion of forests into pasture (Fearnside and Barbosa, 1998; MacGrath et al., 2001) and is in accordance with the preference of $P$. corethrurus for pastures that generally have higher $\mathrm{pH}$ than the original forests. The composition of native communities and their resistance to perturbation, must influence $P$. corethrurus colonization patterns. Once established, populations deeply change the soil morphology at producing huge amounts of casts that end up comprising a very large proportion of the soil volume as stable biogenic aggregates (Blanchart et al., 1999). There is some reason to believe that soils transformed that way do not allow recolonization of native species in cases where forests reestablished. Extinction may thus occur if disturbances affect a large proportion of the distribution area (Lavelle and Lapied, 2003). Further research is needed to test this hypothesis. In any case, our research points to the need of having a large number of relatively small conservation areas rather than large distant units, to conserve earthworm biodiversity in humid tropical areas. However, these conservation areas should be large enough to avoid border effects.

The case of Central American forests, where P. corethrurus was found to dominate earthworm communities of undisturbed forest is intriguing (Lapied and Lavelle, 2003). Two hypotheses may explain this situation. Firstly, these areas may have been deforested in historical times and colonized by $P$. corethrurus, and then reforested. Recolonization by native species did not occur likely because local populations had been eliminated from adjacent areas or were prevented from recolonizing of $P$. corethrurus. Observation of soils colonized by $P$. corethrurus shows that they strongly affect soil physical structure creating aggregation patterns that are rather different from the ones normally observed in natural forests (Hallaire et al., 2000). Apart from this profound alteration of the physical habitat, these aggregates likely have specific microbial communities, which may be a further impediment to the recolonization. Native earthworms may not be able to establish mutualistic relationships with this particular microflora to digest the soil (Trigo et al., 1999; Villenave et al., 1999). An alternative hypothesis is that these areas might be the true center of origin of $P$. corethrurus that would have become the most important species in all land-use systems. There is actually some debate on the real center of origin of $P$. corethrurus. Righi (1984) states that it is located in the Guyanese plateau, but the predominance of the species in most soils of Central America lead to question the issue (Lapied and Lavelle, 2003).

\section{Conclusions}

P. corethrurus, the major invasive earthworm species in the humid tropics, is taking advantage of disturbances created by human activities. In tropical rainforest areas, deforestation destroys the habitat of native species. Most of these species are adapted to forest environments, especially epigeic species that live in the litter layer and the large anecic species that live in soil but partly feed on leaf litter, fail to adapt to the situation created by land conversion, in spite of increased $\mathrm{C}$ and $\mathrm{N}$ contents in soil and decreased acidity. P. corethrurus, by contrast, is favored by such situations and the size of populations that are built seems to be proportional to soil organic matter and nutrient contents and $\mathrm{pH}$. Long term field observations are also needed to evaluate the temporal dynamics of the colonization by $P$. corethrurus and the dispersion pattern.

\section{Acknowledgments}

This work was a part of the Amaz Project (coordinador: Patrick Lavelle) supported by the ANR (Agence Nationale de la Recherche, France), CNPq (Conselho Nacional de Desenvolvimento Científico e Tecnológico) and jointly implemented by IRD (Institut de Recherche pour le Développement), UFPA (Universidade Federal do Pará), UFRA (Universidade Federal Rural da Amazônia), MPEG (Museu Paraense Emílio Goeldi), UTP (Universidad Tecnológica de Pereira-Colombia), CIAT (Colombia). We thank M. L. da Silva and M. N. D. Oliveira for contribution to soil analysis, V. J. Lecomte and Steven Fonte for comments. The authors thank all the people that participated in field and laboratory operations (students, technicians, farmers, field workers, ...).

\section{References}

Alegre, J.C., Pashanasi, B., Lavelle, P., 1996. Dynamics of soil physical properties in a low input agricultural system inoculated with the earthworm Pontoscolex corethrurus in the amazon region of Peru. SSSA J. 60, 1522-1529.

Anderson, J.M., Ingram, J.S.I., 1993. Tropical soil biology and fertility. In: A Handbook of Methods, 2nd ed. CAB International, Wallingford, UK.

Arnauld de Sartre, X., Castro, M., Hubert, B., Oszwald, J., Lavelle, P., Gond, V., Decaëns, T., Michelloti, F., Doledec, S., Sebille, P., Veiga, I., 2010. Scalar organization of reality and social diversity in the ecosystem services assessment. In: Annual Meetings of the Association of American Geographers, Washington, D.C., April 14-18, Session Integrating ecology and political ecology (Session org.: T.J. Bassett; chairman: K.S. Zimmerer).

Barros, E., Curmi, P., Hallaire, V., Chauvel, A., Lavelle, P., 2001. The role of macrofauna in the transformation and reversibility of soil structure of an oxisol in the process of forest to pasture conversion. Geoderma 100, 193-213.

Barros, E., Grimaldi, M., Sarrazin, M., Chauvel, A., Mitja, D., Desjardins, T., Lavelle, P., 2003. Soil physical degradation and changes in macrofaunal communities in Central Amazon. Appl. Soil Ecol. 26, 157-168.

Blanchart, E., Albrecht, A., Alegre, J., Duboisset, A., Pashanasi, B., Lavelle, P., Brussaard, L., 1999. Effects of earthworms on soil structure and physical properties. In Lavelle, P., Brussaard, L., Hendrix, P. (Eds.), Earthworm Management in Tropical Agroecosystems. CAB International, Wallingford, UK, pp. 139-162. 
Bouché, M.B., 1977. Stratégies lombriciennes. Soil organisms as components of ecosystems. Ecol. Bull. (Stockholm), 122-132.

Brown, G., Pashanasi, B., Villenave, C., Patron, J.C., Senapati, B.K., Giri, S., Barois, I., Lavelle, P., Blanchart, E., Blakemore, R.J., Spain, A.V., Boyer, J., 1999. Effects of earthworms on plant production in the tropics. In: Lavelle, P., Brussaard, L., Hendrix, P. (Eds.), Earthworm Management in Tropical Agroecosystems. CAB International, Wallingford, UK, pp. 87-147.

Brown, G.G., James, S.W., Pasini, A., Nunes, D.H., Benito, N.P., Martins, P.T., Sautter, K.D., 2006. Exotic, peregrine, and invasive earthworms in Brazil: diversity, distribution, and effects on soils and plants. Carib. J. Sci. 42, 339-348.

Chapuis-Lardy, L., Brossard, M., Lavelle, P., Schouller, E., 1998. Phosphorus transformations in a ferralsol through ingestion by Pontoscolex corethrurus, a geophagous earthworm. Eur. J. Soil Biol. 34, 61-67.

Chauvel, A., Grimaldi, M., Barros, E., Blanchart, E., Desjardins, T., Sarrazin, M., Lavelle, P., 1999. Pasture damage by an Amazonian earthworm. Nature 398, 32-33.

Chessel, D., Dufour, A.B., Thioulouse, J., 2004. The ade4 package-I-one-table methods. R News 4, 5-10.

Dray, S., Dufour, A.B., 2007. The ade4 package: implementing the duality diagram for ecologists. J. Stat. Soft. 22, 1-20.

Dray, S., Dufour, A.B., Chessel, D., 2007. The ade4 package-II: two-table and K-table methods. R News 7, 47-52.

Fearnside, P.M., Barbosa, R.I., 1998. Soil carbon changes from conversion of forest to pasture in Brazilian Amazonia. Forest Ecol. Man. 108, 147-166.

Garcia, J.A., Fragoso, C., 2002. Growth, reproduction and activity of earthworms in degraded and amended tropical open mined soils: laboratory assays. Appl. Soil Ecol. 20, 43-56.

Gonzales, G., Zou, X., 1999. Earthworm influence on N availability and the growth of Cecropia schreberiana in tropical pasture and forest soils. Pedobiologia 43, 824-829.

Hallaire, V., Curmi, P., Duboisset, A., Lavelle, P., Pashanasi, B., 2000. Soil structure changes induced by the tropical earthworm Pontoscolex corethrurus and organic inputs in a Peruvian ultisol. Eur. J. Soil Biol. 36, 35-44.

Hendrix, P.F., Lachnicht, S.L., Callaham, M.A.J., Zou, X., 1999. Stable isotopic studies of earthworm feeding ecology in tropical ecosystems of Puerto-Rico. Rapid. Commun. Mass Spectrom. 13, 1295-1299.

Hendrix, P.F., Baker, G.H., Callaham, J.A., Damoff, G.A., Fragoso, C., Gonzales, G., James, S.W., Lachnicht, S.L., Winsome, T., Zou, X., 2006. Invasion of exotic earthworms into ecosystem inhabited by native earthworms. Biol. Inv. 8, 1287-1300.

Ihaka, R., Gentleman, R., 1996. R: a language for data analysis and graphics. Comput. Graph. Stat. 5, 299-314.

Lachnicht, S.L., Hendrix, P.F., Zou, X., 2002. Interactive effects of native and exotic earthworms on resource use and nutrient mineralization in a tropical wet forest soil of Puerto Rico. Biol. Fertil. Soils 36, 43-52.

Lafont, A., Risede, J.-M., Loranger-Merciris, G., Clermont-Dauphin, C., Dorel, M., Rhino, B., Lavelle, P., 2007. Effect of the earthworm Pontoscolex corethrurus on banana plants infected or not with the plant-parasitic nematode Radopholus similis. Pedobiologia 51, 311-318.

Lapied, E., Lavelle, P., 2003. The peregrine earthworm Pontoscolex corethrurus in the East coast of Costa Rica. Pedobiologia 47, 471-474.

Lavelle, P., 1981. Stratégies de reproduction chez les vers de terre. Acta Oecol. 2 , 117-133.

Lavelle, P., Barois, I., Cruz, I., Fragoso, C., Hernandez, A., Pineda, A., Rangel, P., 1987. Adaptative strategies of Pontoscolex corethrurus (Glossoscolecidae Oligochaete), a peregrine geophageous earthworm of the humid tropics. Biol. Fertil. Soils 5, $188-194$.
Lavelle, P., Pashanasi, B., 1989. Soil macrofauna and land management in Peruvian Amazonia (Yurimaguas Loreto). Pedobiologia 33, 283-291.

Lavelle, P., Melendez, G., Pashanasi, B., Schaefer, R., 1992. Nitrogen mineralization and reorganization in casts of the geophagous tropical earthworm Pontoscolex corethrurus (Glossoscolecidae). Biol. Fertil. Soils 14, 49-53.

Lavelle, P., Lapied, E., 2003. Endangered earthworms of Amazonia: an homage to Gilberto Righi. Pedobiologia 47, 419-427.

Liu, Z.G., Zou, X.M., 2002. Exotic earthworms accelerate plant litter decomposition in a Puerto Rican pasture and a wet forest. Ecol. Appl. 12, 1406-1417.

Lopez-Hernandez, D., Lavelle, P., Fardeau, J.C., Nino, M., 1993. Phosphorus transformations in two P-sorption contrasting tropical soils during transit through Pontoscolex corethrurus (Glossoscolecidae: Oligochaeta). Soil Biol. Biochem. 25, 789-792.

MacGrath, D.A., Smith, C.K., Gholz, H.L., de Assis Oliveira, F., 2001. Effects of land-use change on soil nutrient dynamics in Amazonia. Ecosystem 4, 625-645.

McLean, M.A., Migge-Kleian, S., Parkinson, D., 2006. Earthworm invasions of ecosystems devoid of earthworms: effects on soil microbes. Biol. Inv. 8, 12571273.

Nunes, D.H., Pasini, A., Benito, N.P., Brown, G.G., 2006. Earthworm diversity in four land use systems in the region of Jaguapitã, Paraná State, Brazil. Carib. J. Sci. 3 331-338.

Ortiz-Ceballos, A.I., Fragoso, C., Equihua, M., Brown, G.G., 2005. Influence of food quality, soil moisture and the earthworm Pontoscolex corethrurus on growth and reproduction of the tropical earthworm Balanteodrilus pearsei. Pedobiologia 49, 89-98.

Pashanasi, B., Lavelle, P., Alegre, J., Charpentier, F., 1996. Effect of the endogeic earthworm Pontoscolex corethrurus on soil chemical characteristics and plant growth in a low-input tropical agroecosystem. Soil Biol. Biochem. 28, 801-810.

R-Development-Core-Team, 2009. R: A Language and Environment for Statistical Computing. R Foundation for Statistical Computing, Vienna, Austria, ISBN 3900051-07-0, URL http://www.R-project.org.

Righi, G., 1984. Pontoscolex (Oligochaeta:Glossoscolecidae), a new evaluation. S. Neotrop. Faun. Environ. 19, 159-177.

Rose, C.J., Wood, A.W., 1980. Some environmental factors affecting earthworm populations and sweet potato production in the Tari Basin Papua new Guinea highlands. P.N.-G. Agric. J. 31, 1-13.

Rossi, J.-P., Celini, L., Mora, P., Mathieu, J., Lapied, E., Nahmani, J., Ponge, J.F., Lavelle, P., 2010. Decreasing fallow duration in tropical slash-and-burn agriculture alters soil macroinvertebrate diversity: a case study in southern French Guiana. Agric. Ecosyst. Environ. 135, 148-154.

Sanchez-de Leon, Y., Zou, X., Borges, S., Ruan, H., 2004. Recovery of native earthworms in abandoned tropical pastures. Cons. Biol. 17, 999-1006.

Trigo, D., Barois, I., Garvin, M.H., Huerta, E., Irisson, S., Lavelle, P., 1999. Mutualism between earthworms and soil microflora. Pedobiologia 43, 866-873.

Villenave, C., Charpentier, F., Lavelle, P., Feller, C., Brussaard, L., Pashanasi, B., Barois I. Albrecht, A., Patron, J.C., 1999. Effects of earthworms on soil organic matter and nutrient dynamics following earthworm inoculation in field experimental situations. In: Lavelle, P., Brussaard, L., Hendrix, P. (Eds.), Earthworm Management in Tropical Agroecosystems. CAB International, Wallingford, UK, pp. 173197.

Zou, X., 1993. Species effects on earthworm density in tropical tree plantations in Hawaï. Biol. Fertil. Soils 15, 627-629.

Zou, X., Gonzalez, G., 1997. Changes in earthworm density and community structure during secondary succession in abandoned tropical pastures. Soil Biol. Biochem. 29, 627-629. 